\title{
Pollution and a Million Flamingos
}

\author{
Sir Landsborough Thomson
}

In the last issue of ORYX we drew attention to the dangers from chemicals for the bird life of the Rift Valley lakes in East Africa (page 283). This is particularly serious in Lake Nakuru where a million flamingos are threatened by both chemicals and the sewage effluent from the town of Nakuru which all goes untreated into the lake. Sir Landsborough points out that only on the basis of facts will the authorities listen to demands that the pollution be stopped-and that means research. The new Baharini Wildlife Sanctuary has been established on the lake shores with the triple purpose of providing facilities for such research, as well as for education and tourism-the last designed eventually to pay for the first two. But money is needed to get the research started now. The originator of the project, John Hopcraft, spoke about it at an FPS meeting on September 22, and a letter from Sir Landsborough was published by The Times on September 21. The World Wildlife Fund is supporting the project and the FPS will be pleased to pass on contributions from any members or others who would like to help save the Nakuru flamingos.

Twice within the last twelve months I have been privileged to see one of the great bird spectacles of the world, the massed flamingos on Lake Nakuru, in the Rift Valley of Kenya; the numbers seem to fluctuate around the million mark. The impression one gets is of flock after tightly packed flock lining miles of shore. From a distance, or from the air, they form a solid band of pink; closer, as one can readily go, both individual and social behaviour can be observed. Lesser flamingos make up the great bulk of the flocks, with a minority of greater flamingos. There are in addition substantial numbers of pelicans, and a good representation of such families as the storks, ibises, herons, ducks, plovers and grebes. At the north end a colony of some two hundred cormorants nest in a group of gaunt dead trees standing in the water. Apart from birds, a small herd of hippopotamus inhabits one corner of the lake and several species of antelope may be seen around it, including defassa waterbuck and bohor reedbuck; also a few buffalo and an occasional leopard.

The flamingos do not nest on Lake Nakuru but on several other lakes in the area; it is nevertheless a key-point in the ecology of a large population of these strange and beautiful birds. They congregate there to feed on the blue-green algae that multiply so abundantly in the markedly alkaline water and can be extracted by the specialised filtration apparatus within the bill. The lake is fed by several small rivers but has no apparent outlet; it is quite shallow, and evaporation must be high under the tropical sun that produces heat shimmer over the surface. It lies a little south of the Equator, and some 6000 feet above sea-level, 
among hills and acacia woodlands; it measures about six miles long by four at the widest. The area of the lake has been declared a National Park, although including a narrower strip of surrounding shore than one would wish. There is thus protection in the legal sense, as well as provision for access by visitors.

The threat that impends over this wonderful scene is that of pollution. The sewage of the adjacent town of some 40,000 inhabitants, with the effluent of a considerable industrial development, is discharged into the lake; perhaps worse, the rivers bring in the run-off from cultivated land heavily treated with persistent chemicals. There is thus a very real danger that these inimical factors may build up to a point where the chemical balance of the lake would be upset and its ecological value expunged for ever. And this could, one fears, happen quite suddenly.

One simply does not know how near the danger is, how quickly it is approaching, or what the critical point may be. These matters must be ascertained before it is too late, because it is only on a basis of sound knowledge that a strong case for drastic action can be made. There is thus an urgent demand for hydrological research as a practical necessity; and there are also many significant biological problems awaiting study of the rich material that is available.

A project for this purpose has been launched under the inspiration of John Hopcraft, member of a family long established in Kenya and himself an able ornithologist trained in conservation science at Cornell University. A charitable trust called Baharini Wildlife Sanctuary has been formed with a board of governors consisting of scientists and conservationists from Kenya and elsewhere, and John Hopcraft as the executive director. The Baharini estate of about 1600 acres, with a frontage of nearly two miles on the northern foreshore, is being acquired by Kenya National Parks and will be leased to the trust. On this strategic site are to be built a research laboratory, an educational centre, and a lodge for the accommodation of visitors to the Park; imaginative plans for these buildings already exist. Eventually the profits of the lodge should maintain the whole enterprise, but for some years the cost will have to be met from grants and donations. An initial grant has already been given by the World Wildlife Fund, and approaches are now being made to foundations, institutions and individuals likely to be interested in furthering the cause. It is hoped that many members of the public may also be moved to subscribe smaller sums, and the World Wildlife Fund (British National Appeal) is in a position to accept contributions earmarked for the Baharini project. Fuller particulars of the scheme can be obtained by writing to the Fund's office at 7 Plumtree Court, London, EC4.

\section{Field Biology Certificate}

The University of London's Certificate in Field Biology is open to anyone interested in the study of living things in their natural habitats. Applications for the 197 I course to the Assistant Director (Room I4), Department of Extra-Mural Studies, University of London, 7 Ridgmount Street, London WCIE $7 \mathrm{AD}$. 